\title{
Jual Beli Dengan Hak Membeli Kembali (Studi Komparasi Antara Kitab Undang-Undang Hukum Perdata dan Fikih Syafi'i)
}

\author{
Dewi Wulan Fasya \\ Fakultas Syariah UIN Maulana Malik Ibrahim Malang \\ pasya_dejafa@yahoo.com
}

\begin{abstract}
:
This article seeks to examine the concept of buying and selling the right to buy back the book review law and civil law bai 'al-Wafa, according to the Shafi'i fiqh. In addition, this article also aims to determine the ratio of the purchase with repurchase review the statute books of civil law and bai al-Wafa, according to the Shafi'i fiqh. Based on the discussion of this article indicates that the purchase is a period of time agreed to recall goods that have been sold and the sale can not be more than five years. While bai 'al-Wafa, according to the Shafi'i fiqh of buying and selling that took sides coupled with the condition that the sale could be bought back by the seller, when the time limit has been determined arrive, while the goods sold are free to be used by the buyer. In sale and purchase of the right to buy back also set about replacement care costs of goods and so forth, while bai 'alWafa there is no mention of the replacement cost of care, which is paid only the cost of the initial purchase, the last of the law of sale and purchase with a repurchase in KUHPerdata much contested in the Supreme court decision which MA. No. 1729 K / Pdt / 2004, which stated that the purchase of the right to buy back is not allowed, while bai 'al-Wafa laws in Shafi'i fiqh books Raghibin Kanz al-Minhaj Fi Sharh al-Thalibin a transaction is fasid.
\end{abstract}

Artikel ini bertujuan mengetahui konsep jual beli dengan hak membeli kembali tinjauan kitab undang-undang hukum perdata dan bai al-wafâ menurut fikih Syafi'i. Selain itu, artikel ini juga bertujuan untuk mengetahui perbandingan dari jual beli dengan hak membeli kembali tinjauan kitab undang-undang hukum perdata dan bai al-wafâ menurut fikih Syafi'i. Berdasarkan uraian pembahasan artikel ini menunjukkan bahwa dalam jual beli ini ada suatu jangka waktu tertentu yang diperjanjikan untuk menebus kembali barang yang telah dijual dan jangka waktu jual beli ini tidak boleh lebih dari lima tahun. Sedangkan bai' al-wafâ menurut fikih Syafi'i yaitu jual beli yang dilangsungkan dua pihak yang dibarengi dengan syarat bahwa yang dijual itu dapat dibeli kembali oleh penjual, apabila tenggang waktu yang telah ditentukan tiba, sedangkan barang yang dijual tersebut bebas dipergunakan oleh pembeli. Dalam jual beli dengan hak membeli kembali juga mengatur tentang penggantian biaya perawatan barang dan lain sebagainya, sedangkan bai' al-wafâ tidak ada menyinggung tentang penggantian biaya perawatan, yang dibayarkan hanya harga awal pembelian, terakhir mengenai hukum dari jual beli dengan hak membeli kembali dalam KUHPerdata banyak dipertentangkan dalam putusan Mahkamah Agung diantaranya Putusan MA. No. $1729 \mathrm{~K} / \mathrm{Pdt} / 2004$ yang menyatakan bahwa jual beli dengan hak membeli kembali tidak diperbolehkan, sedangkan bai' al-wafâ hukumnya dalam fikih Syafi'i kitab Kanz al-Râghibin Fi Syarh Minhaj al-Thâlibin merupakan jual beli yang fasid

Kata Kunci: Jual beli; Hak Membeli Hembali, fikih Syafi'i 


\section{Pendahuluan}

Manusia merupakan makhluk sosial yang tidak bisa lepas dari interaksi dengan manusia yang lain. Dalam kehidupan sehari-harinya manusia sebagai makhluk sosial tidak akan luput dari pemenuhan kebutuhan hidupnya. Untuk memenuhi kebutuhan hidupnya tersebut, manusia mengembangkan kemampuan dan akalnya. Kemudian dari sini proses ekonomi (muamalah) muncul, ketika manusia tidak dapat memenuhi kebutuhannya sendiri sehingga diperlukan transaksi ekonomi (muamalah) untuk memenuhi kebutuhan hidupnya. Selanjutnya kebutuhan ekonomi (muamalah) tersebut dimanifestasikan dalam bentuk jual beli dengan menggunakan media uang sebagai alat tukar. Jual beli membawa dua aspek penting dalam hukum perdata. Pertama, adalah kegiatan menjual, yang secara sederhana menunjukkan pada suatu proses atau kegiatan yang bertujuan untuk mengurangi jumlah harta kekayaan seseorang, pada satu sisi, yang merupakan suatu bentuk kewajiban, prestasi atau utang yang harus dipenuhi.

Kedua, pada sisi timbal balik, kegiatan membeli tersebut, melahirkan suatu bentuk tagihan atau hak yang merupakan kebendaan tidak berwujud yang bergerak. Kedua hal tersebut ada secara timbal balik, pada "saat yang bersamaan" pada kedua belah pihak yang membuat perjanjian tersebut. Jadi dalam jual beli terjadi dua sisi hukum perdata, yaitu hukum kebendaan dan hukum perikatan secara bersama-sama. Sebagaimana menurut Pasal 1457 KUHPerdata menjelaskan: "Jual beli adalah suatu perjanjian, dengan mana pihak yang satu mengikatkan dirinya untuk menyerahkan suatu kebendaan, dan pihak yang lain untuk membayar harga yang telah dijanjikan”. Berdasarkan pada rumusan tersebut bahwa jual beli merupakan salah satu bentuk perjanjian yang melahirkan kewajiban atau perikatan untuk memberikan sesuatu, yang dalam hal ini terwujud dalam bentuk penyerahan kebendaan yang dijual oleh penjual, dan penyerahan uang oleh pembeli kepada penjual. Jual beli dengan hak membeli kembali yang merupakan salah satu dari perkembangan transaksi yang terjadi di masyarakat berupa bentuk perjanjian yakni penjual (pemilik semula) mempunyai atau diberikan hak dengan suatu perjanjian untuk membeli kembali barangnya yang telah dijual tersebut (pasal 1519 KUHPerdata).

Jual beli dengan hak membeli kembali sebagaimana diatur dalam Pasal 1519 KUHPerdata

' 'Kekuasaan untuk membeli kembali barang yang telah dijual diterbitkan dari suatu janji, dimana si penjual diberikan hak untuk mengambil kembali barang yang dijualnya, dengan mengembalikan harga pembelian asal yang disertai penggantian yang disebutkan dalam Pasal 1532 KUHPerdata. Putusan Mahkamah Agung Republik Indonesia Nomor 1729 PK/Pdt/2004 tentang jual beli dengan hak membeli kembali. ${ }^{1}$ Menurut putusan tersebut perjanjian jual beli dengan hak membeli kembali yang diatur dalam Pasal 1519 KUHPerdata, adalah tidak diperbolehkan, karena beberapa hal :1. Perjanjian jual beli dengan hak membeli kembali adalah perjanjian hutang-piutang yang terselubung (semu). Artinya, bahwa perjanjian jual beli dengan hak membeli kembali sebenarnya adalah perjanjian hutang piutang, yakni pemberian pinjaman dengan jaminan. 2. Perjanjian jual beli dengan hak membeli kembali bertentangan dengan hukum adat, karena hukum adat tidak mengenal jual beli dengan hak untuk membeli kembali.

Sedangkan dalam hukum Islam, jual beli dengan hak membeli kembali masih diperdebatkan hukumnya. Dalam buku kaidah-kaidah fikih muamalah dan aplikasinya dalam ekonomi Islam dan perbankan syariah karya Abbas Arfan, dijelaskan bahwa menurut Musthafa Ahmad al-Zarqa, para ulama terpecah menjadi 3 (tiga) pendapat dalam menyikapi hukum bai' al-wafâ yaitu : 1) jual beli yang sah sebagai akad jual beli bersyarat, 2) jual beli

\footnotetext{
${ }^{1}$ Suharnoko, Hukum Perjanjian : Teori Dan Analisa Kasus (Jakarta: Kencana Prenada Media Group, 2004$), 29$.
} 
yang sah namun menjadi hukum rahn (gadai), dan 3) jual beli yang tidak sah. ${ }^{2}$ Dalam Islam ada bentuk transaksi jual beli yang dibolehkan dan ada yang diharamkan maupun diperselisihkan hukumnya. Allah telah menghalalkan segala bentuk jual beli selama sesuai dengan syariat, hal ini telah diatur dalam al-Quran. Allah berfirman dalam surah al-Baqarah ayat 282:

Hai orang-orang yang beriman, apabila kamu bermuamalah tidak secara tunai untuk waktu yang ditentukan, hendaklah kamu menuliskannya. dan hendaklah seorang penulis di antara kamu menuliskannya dengan benar. ${ }^{3}$

Allah telah menjelaskan di dalam ayat tersebut hendaklah mencatat setiap transaksi yang dilakukan secara tidak tunai untuk waktu yang ditentukan. Hal ini merupakan antisipasi terhadap transaksi yang merugikan salah satu pihak. Jual beli dengan hak membeli kembali ini unik, karena dalam perjanjiannya disebutkan bahwa pihak penjual mempunyai hak untuk membeli kembali barang yang telah dijualnya kepada pembeli dengan mengembalikan harga pembelian yang telah diterimanya disertai semua biaya yang telah dikeluarkan oleh pihak pembeli dalam menyelenggarakan pembelian dan biaya-biaya lainnya untuk perawatan barang yang dibelinya, ini yang menyebabkan bertambahnya harga barang yang ingin dibeli kembali oleh si penjual.

Dalam prakteknya penulis menemukan perjanjian dengan hak membeli kembali pada transaksi yang terdapat di Koperasi Wanita (KOPWAN) desa Racik kecamatan Bangil. Pada saat penulis melaksanakan PKLI di kecamatan Bangil, penulis mengamati pada kenyataannya jual beli dengan hak membeli kembali merupakan jual beli semu karena yang terjadi adalah hutang piutang. Dimana seseorang yang membutuhkan uang pergi ke koperasi kemudian antara pemilik barang dengan pihak koperasi melakukan transaksi yakni pemilik barang menjual barang yang dia miliki kepada koperasi wanita kemudian si pemilik barang akan membeli kembali barangnya tersebut pada jangka waktu tertentu dengan harga lebih tinggi dari harga pertama saat penjualan pada koperasi wanita. ${ }^{4}$ Sehingga inconcreto bagi hukum yang terjadi bukan jual beli, melainkan persetujuan hutang dengan agunan yang bersifat seolah-olah hubungan gadai yakni peminjaman dengan jaminan. Hal inilah yang melatarbelakangi penulis untuk meneliti tentang hukum yang ada pada transaksi jual beli dengan hak membeli kembali. Berdasarkan uraian di atas, artikel ini bertujuan mengetahui konsep jual beli dengan hak membeli kembali tinjauan kitab undang-undang hukum perdata dan bai al-wafâ menurut fikih Syafi'i. Selain itu, artikel ini juga bertujuan untuk mengetahui perbandingan dari jual beli dengan hak membeli kembali tinjauan kitab undang-undang hukum perdata dan bai al-wafâ menurut fikih Syafi'i.

\section{Metode Penlitian}

Penelitian ini termasuk jenis penelitian yuridis normatif ${ }^{5}$ karena berupaya mengkaji aspek yuridis dari proses jual beli dengan hak membeli kembali dalam hukum Islam dan KUHPerdata. Penelitian ini menggunakan pendekatan perundang-undangan (statute approach), karena yang diteliti adalah berbagai aturan hukum yang menjadi fokus penelitian. ${ }^{6}$ Penulis juga menggunakan pendekatan konseptual (conceptual approach), yaitu menelaah konsep yang beranjak dari pandangan dan doktrin yang berkembang dalam ilmu hukum dan

\footnotetext{
${ }^{2}$ Abbas Arfan, Kaidah-Kaidah Fikih Muamalah Dan Aplikasinya Dalam Ekonomi Islam \& Perbankan Syariah (Malang: UIN-Malang Press, 2012), 117.

${ }^{3}$ Departemen Agama RI, Al-Hikmah, Al-Qur'an dan Terjemahnya (Bandung: Diponegoro, 2009), 48.

${ }^{4}$ Koperasi Wanita Desa Raci Kecamatan Bangil, Wawancara, (Bangil, 9 Juli 2014).

${ }^{5}$ Bahder Johan Nasution, Metode Penelitian Ilmu Hukum (Bandung: Mandar Maju, 2008), 86.

${ }^{6}$ Johnny Ibrahim, Teori Dan Metode Penelitian Hukum Normatif (Malang: Bayu Media Publishing, 2006$), 302$.
} 
agama. $^{7}$ Bahan Hukum ${ }^{8}$ Primer yang digunakan yaitu: 1) Kitab Undang-Undang Hukum Perdata (KUHPerdata). 2) Kitab fikih Syafi'i yaitu Kanz al-Râghibîn Fi Syarh Minhaj alThâlibîn karya Jalâl al-Dîn Muhammad bin Ahmad al-Mahallî. Sedangkan bahan hukum sekunder ${ }^{9}$ yang digunakan meliputi fikih muamalah mengenai berbagai literatur tentang jual beli, hukum jual beli, jual beli dengan hak membeli kembali, bai' wafâ dan literatur lain yang berhubungan dengan topik pembahasan. Penulis juga menggunakan buku-buku hukum perdata yang berhubungan dengan jual beli dengan hak membeli kembali.

\section{Hasil dan Pembahasan \\ Konsep Jual Beli Dengan Hak Membeli Kembali Menurut Kitab Undang-Undang Hukum Perdata}

Jual beli membawa dua aspek penting dalam hukum perdata, pertama adalah kegiatan menjual, yang secara sederhana menunjukkan pada suatu proses atau kegiatan yang bertujuan untuk mengurangi jumlah harta kekayaan seseorang, pada satu sisi, yang merupakan suatu bentuk kewajiban, prestasi atau utang yang harus dipenuhi. Kedua, pada sisi yang bertimbal balik, kegiatan membeli tersebut, melahirkan suatu bentuk tagihan atau hak yang merupakan kebendaan tidak berwujud yang bergerak. Kedua hal tersebut ada secara bertimbal balik, pada "saat yang bersamaan" pada kedua belah pihak yang membuat perjanjian tersebut. Jadi dalam jual beli terjadi dua sisi hukum perdata, yaitu hukum kebendaan dan hukum perikatan secara bersama-sama. Sebagaimana disebutkan Pasal 1457 KUHPerdata menjelaskan: "Jual-beli adalah suatu perjanjian, dengan mana pihak yang satu mengikatkan dirinya untuk menyerahkan suatu kebendaan, dan pihak yang lain untuk membayar harga yang telah dijanjikan".

Berdasarkan rumusan tersebut bahwa jual beli merupakan salah satu bentuk perjanjian yang melahirkan kewajiban atau perikatan untuk memberikan sesuatu, yang dalam hal ini terwujud dalam bentuk penyerahan kebendaan yang dijual oleh penjual, dan penyerahan uang oleh pembeli kepada penjual. ${ }^{10}$ Menurut Pasal 1519 KUHPerdata: "Kekuasaan untuk membeli kembali barang yang telah dijual diterbitkan dari suatu janji, dimana si penjual diberikan hak untuk mengambil kembali barang yang dijualnya, dengan mengembalikan harga pembelian asal yang disertai penggantian yang disebutkan dalam Pasal 1532 KUHPerdata". Penggantian di dalam Pasal 1532 adalah penggantian biaya menyelengarakan pembelian dan penyerahan serta perbaikan terhadap barang tersebut. Artinya, apabila tidak bertentangan perjanjian tersebut sebenarnya dapat dilaksanakan, apalagi tujuan utama dari perjanjian jual beli dengan hak membeli kembali, adalah untuk menolong golongan ekonomi lemah untuk memperoleh kredit. Dengan demikian perjanjian jual beli dengan hak untuk membeli kembali diperbolehkan selama tidak bertentangan dengan asas kepatutan, ketertiban umum dan kesusilaan sebagaimana Pasal 1337 KUHPerdata, Serta syarat sahnya perjanjian dalam Pasal 1320 KUHPerdata yang menjelaskan : 1) Sepakat mereka yang mengikatkan dirinya; 2) Kecakapan untuk membuat suatu perikatan; 3) Suatu hal tertentu; 4) Suatu sebab yang halal. Obyek dari perjanjian jual beli adalah barang-barang tertentu yang dapat ditentukan wujud dan jumlahnya serta tidak dilarang menurut hukum yang berlaku untuk diperjual belikan karena perjanjian jual beli telah sah mengikat apabila kedua belah pihak telah mencapai kata sepakat tentang barang dan harga meski barang tersebut belum diserahkan maupun harganya belum dibayarkan (Pasal 1458 KUHPerdata).

\footnotetext{
${ }^{7}$ Abdulkadir Muhammad, Hukum Dan Penelitian Hukum (Bandung: Citra Aditya Bakti, 2004), 113.

${ }^{8}$ Peter Mahmud Marzuki, Penelitian Hukum (Jakarta: Kencana, 2010), 41.

${ }^{9}$ Soerjono Soekanto and Sri Mamudji, Penelitian Hukum Normatif: Suatu Tinjauan Singkat (Jakarta:

RajaGrafindo Persada, 2006), 24.

${ }^{10}$ Gunawan Widjaja and Kartini Muljadi, Jual Beli (Jakarta: RajaGrafindo Persada, 2003), 7.
} 
Perjanjian jual beli dapat dibatalkan apabila si penjual telah menjual barang yang bukan miliknya atau barang yang akan dijual tersebut telah musnah pada saat penjualan berlangsung. Kewajiban Penjual Dari ketentuan umum mengenai perikatan untuk menyerahkan sesuatu menurut Pasal 1235 Kitab Undang-Undang Hukum Perdata, dan ketentuan yang diatur secara khusus dalam ketentuan jual beli menurut Pasal 1474 Kitab Undang-Undang Hukum Perdata, penjual memiliki tiga kewajiban pokok, mulai dari sejak jual beli terjadi menurut ketentuan Pasal 1458 Kitab Undang-Undang Hukum Perdata. Menurut Ketentuan tersebut, secara prinsip penjual memiliki kewajiban untuk : a) Memelihara dan merawat kebendaan yang akan diserahkan kepada pembeli hingga saat penyerahan; b) Menyerahkan kebendaan yang dijual pada saat yang telah ditentukan, atau jika tidak telah ditentukan saatnya, atas permintaan pembeli; c) Menanggung kebendaan yang dijual tersebut. Dibandingkan dengan kewajibannya, hak penjual lebih banyak. Selama pemilik barang belum mempergunakan haknya untuk membeli, penjual mempunyai kedudukan sebagai pemilik yang sempurna dan memperoleh segala hak yang semula berada ditangan pembeli. Penjual berhak menggunakan daluarsa terhadap pemilik sejati, maupun terhadap orang yang memiliki hak-hak hipotik atau hak-hak lain atas barang yang dijual. Jadi seketika pada waktu jangka waktu telah lewat dan pembelil tidak menggunakan hak membeli kembalinya, penjual menjadi pemilik sejati dari barang dan tidak dapat dituntut untuk menyerahkan barang tersebut kepada pihak lain yang memiliki hipotik atau hak lain atas barang itu. ${ }^{11}$

Pasal 1531 Kitab Undang-Undang Hukum Perdata menyebutkan jika penjual meninggalkan beberapa ahli waris maka masing-masing ahli waris ini hanya berhak menyerahkan kembali sebesar bagiannya masingmasing kepada pemilik barang, kecuali jika barang warisan telah dibagi dan barang yang dijual jatuh pada salah seorang ahli waris, ahli waris ini dapat menyerahkan barang keseluruhan kepada penjual. Kewajiban penjual yang utama dalam perjanjian jual beli dengan hak membeli kembali ialah menyerahkan barang yang menjadi objek jual beli ketika penjual menggunakan hak membeli kembali. Kewajiban pembeli dapat ditarik dari ketentuan pasal 1265 Ayat (2) KUHPerdata tentang syarat batal menjelaskan: "Syarat ini tidak menangguhkan pemenuhan perikatan, hanyalah ia mewajibkan si berpiutang mengembalikan apa yang telah diterimanya, apabila peristiwa yang dimaksudkan terjadi”.

Adapun kewajiban Pembeli Kewajiban pembeli yang utama dalam perjanjian jual beli dengan hak membeli kembali ialah menyerahkan barang yang menjadi obyek jual beli ketika penjual menggunakan hak membeli kembalinya. Kewajiban pembali dapat ditarik dari ketentuan pasal 1265 tentang syarat batal. Ayat-ayatnya berbunyi "syarat ini tidak menangguhkan pemenuhan perikatan hanyalah ia mewajibkan si berpiutang mengembalikan apa yang telah diterimanya, apabila peristiwa yang dimaksudkan terjadi. Kewajiban pembeli menurut Pasal 1513 Kitab Undang-Undang Hukum Perdata ialah membayar harga pembelian pada waktu dan tempat sebagaimana ditetapkan menurut persetujuan. Batas waktu jual beli dengan hak membeli kembali Batas waktu hak membeli kembali itu tidak bisa diperjanjikan lebih lama dari lima tahun, tetapi apabila telah diperjanjikan untuk waktu lebih dari lima tahun maka yang berlaku adalah lima tahun. Batas waktu ini mutlak, sehingga hakimpun tidak boleh memperpanjang, apabila penjual lalai mengajukan tuntutannya untuk membeli kembali barangnya dalam tenggang waktu yang telah ditetapkan, maka si pembeli tetap menjadi pemilik atas barang yang dibeli tersebut dan akan menjadi pemilik tetap. ${ }^{12}$

Dapat dilihat dalam pasal 1520 Kitab Undang-Undang Hukum Perdata yaitu " Hak membeli kembali tidak boleh diperjanjikan untuk suatu waktu yang lebih lama dari lima

\footnotetext{
${ }^{11}$ Subekti and R. Tjitrosudibio, Kitab Undang-Undang Hukum Perdata (Jakarta: Pradnya Paramita, 2007 ), 277.

12 I.G. Rai Widjaya, Merancang Suatu Kontrak (Contract Drafting), Teori Dan Praktek (Jakarta: Megapoin, 2003), 134.
} 
tahun, jika hak tersebut diperjanjikan untuk suatu waktu yang lebih lama, maka waktu itu diperpendek sampai lima tahun. ${ }^{13}$ Jual beli dengan hak membeli kembali disebutkan bahwa pihak penjual mempunyai hak untuk membeli kembali barang yang telah dijualnya kepada pembeli dengan mengembalikan harga pembelian yang telah diterimanya disertai semua biaya yang telah dikeluarkan oleh pihak pembeli untuk menyelenggarakan pembelian serta penyerahannya, termasuk juga biaya-biaya pembetulan dan pengeluaran-pengeluaran yang menyebabkan barang yang dijual bertambah harganya. Sebenarnya jual beli dengan hak membeli kembali adalah suatu pinjam meminjam uang yang dilakukan dengan jual beli dengan kemungkinan penjual untuk membeli kembali barangnya jika telah memiliki uang. Dalam jual beli ini ada suatu jangka waktu tertentu yang diperjanjikan untuk menebus kembali barang yang telah dijual dan jangka waktu jual beli ini tidak boleh lebih dari lima tahun.

Seperti yang telah dijelaskan menurut pasal 1519 KUHPerdata, kekuasaan untuk membeli kembali barang yang telah dijual diterbitkan dari suatu janji, dimana si penjual diberikan hak untuk mengambil kembali barang yang dijualnya, dengan mengembalikan harga pembelian asal yang disertai penggantian yang disebutkan dalam Pasal 1532 KUHPerdata. Penggantian di dalam Pasal 1532 adalah penggantian biaya menyelengarakan pembelian dan penyerahan serta perbaikan terhadap barang tersebut adalah hal yang wajar, pembeli tentunya membutuhkan biaya administrasi atau pemeliharaan untuk menjaga dan memperbaiki barang tersebut. Misalnya, biaya pembuatan akta dan memelihara obyek perjanjian. Bahwa oleh karena dalam persetujuan hanya ada satu pihak yang berprestasi, maka persetujuan yang demikian dinamakan perjanjian sepihak, dan pada sisi lain karena persetujuan atas beban melahirkan perikatan secara timbal balik pada kedua belah pihak, maka disebut sebagai perjanjian timbal balik. Dengan demikian, berarti janji untuk membeli kembali adalah kewajiban (prestasi) yang harus dipenuhi oleh pembeli kepada penjual, selain daripada prestasi pokok untuk membayar harga kebendaan yang dibeli tersebut. Hal membeli kembali merupakan suatu hak yang diberikan oleh Undang-Undang berdasarkan pada perjanjian yang dibuat oleh para pihak.

Selama biaya-biaya tersebut dan harga pembelian oleh pembeli belum dilunasi oleh penjual yang memiliki janji membeli kembali tersebut, maka pembeli tersebut tidak memiliki kewajiban untuk menyerahkan kebendaan tersebut kepada pembeli. Bahkan pembeli berhak untuk menuntut penguasaan kembali kebendaan yang dijanjikan untuk dibeli kembali tersebut, dari tangan penjual, selama biaya-biaya tersebut belum dilunasi oleh penjual dengan janji membeli kembali. Untuk memberikan kepastian hukum bagi pembeli, maka dalam rumusan Pasal 1520 jo. Pasal 1521 Kitab Undang-Undang Hukum Perdata menentukan suatu jangka waktu yang pasti, yang tidak boleh disimpangi bahkan oleh suatu penetapan atau keputusan pengadilan yang berwenang. Di dalam hukum adat tidak mengenal adanya perjanjian jual beli dengan hak membeli kembali dan hanya dianggap sebagai perjanjian gadai belaka. Mengingat transaksi peralihan hak atas tanah sesuai pasal 5 UUPA No.5/1960 dikuasai oleh hukum adat, sedangkan hukum adat tidak mengenal jual beli dengan hak membeli kembali, untuk itu dipakai lembaga gadai. Oleh karena itu berdasarkan UndangUndang Pokok Agraria No.5/1960 itu sendiri maka jual beli dengan hak membeli kembali mengenai tanah dan rumah adalah batal demi hukum. ${ }^{14}$

Putusan Mahkamah Agung Republik Indonesia Nomor 1729 K/Pdt/2004 tentang jual beli dengan hak membeli kembali. Menurut putusan tersebut perjanjian jual beli dengan hak membeli kembali yang diatur dalam Pasal 1519 KUHPerdata, adalah tidak diperbolehkan, karena beberapa hal: a) Perjanjian jual beli dengan hak membeli kembali adalah perjanjian

\footnotetext{
${ }^{13}$ Subekti and Tjitrosudibio, Kitab Undang-Undang Hukum Perdata, 376.

${ }^{14}$ Undang-Undang Nomor 5 Tahun 1960tentang Pokok-Pokok Agraria
} 
hutang-piutang yang terselubung (semu). Artinya, bahwa perjanjian jual beli dengan hak membeli kembali sebenarnya adalah perjanjian hutang piutang, yakni pemberian pinjaman dengan jaminan; b) Perjanjian jual beli dengan hak membeli kembali bertentangan dengan hukum adat, karena hukum adat tidak mengenal jual beli dengan hak untuk membeli kembali. Dalam suatu perjanjian jual-beli dengan hak membeli kembali itu sudah barang tentu dikandung maksud bahwa si pembeli selama jangka waktu yang diperjanjikan itu tidak akan menjual lagi barangnya kepada orang lain, karena ia setiap waktu dapat diminta menyerahkan kembali barang itu kepada si penjual. Namun kalau menjual barangnya kepada orang lain, dan barang ini adalah barang bergerak, maka pembeli kedua ini adalah aman, artinya tidak dapat dituntut untuk menyerahkan barangnya kepada si penjual pertama. Orang ini (penjual pertama) hanya dapat menuntut ganti-rugi dari si pembeli (pertama) yang telah membawa dirinya dalam keadaan tidak mampu memenuhi janjinya. Lain halnya apabila yang diperjualbelikan itu suatu benda tak bergerak.

Dalam hal ini si penjual yang telah meminta diperjanjikan kekuasaannya untuk membeli kembali barang yang di jual, boleh menggunakan haknya itu terhadap seorang pembeli kedua, meskipun dalam perjanjian jual-beli yang kedua itu tidak disebutkan tentang adanya janji tersebut, ini berarti bahwa, jika yang diperjual-belikan itu suatu benda tak bergerak, maka janji untuk membeli kembali yang telah diadakan untuk kepentingan si penjual itu harus ditaati oleh pihak ketiga. Dapat diketahui bahwa perjanjian jual beli dengan hak membeli kembali yang banyak digunakan oleh masyarakat tujuannya adalah untuk memperkuat kedudukan kreditur terhadap debitur, sekaligus juga memperkuat posisi kreditur terhadap pihak ketiga. Akan tetapi karena syarat pembuktiannya adalah berat dan perjanjian jual beli dengan hak membeli kembali mengenai barang yang tidak bergerak seperti tanah dan atau rumah selalu terjadi dengan suatu akta autentik sehingga sulit bagi debitur untuk membuktikan akta tersebut tidak sah dan sering kali penjual atau debitur tidak berhasil untuk membuktikan bahwa yang sebenarnya terjadi adalah hutang piutang. Dapat dikatakan dalam perjanjian jual beli dengan hak membeli kembali terdapat keadaan yang tidak seimbang sehingga salah satu pihak ada yang dirugikan karena adanya penyalahgunaan keadaan/kesempatan ataupun penyalahgunaan ekonomis.

Dari penjelasan-penjelasan diatas dapat dipahami bahwa perjanjian jual beli dengan hak membeli kembali adalah perjanjian hutang-piutang yang terselubung (semu). Artinya, bahwa perjanjian jual beli dengan hak membeli kembali sebenarnya adalah perjanjian hutang piutang, yakni pemberian pinjaman dengan jaminan. Sehingga dapat diamati bahwa inkonkreto bagi hukum yang terjadi bukan jual beli, melainkan persetujuan hutang dengan agunan yang bersifat seolah-olah hubungan gadai yakni peminjaman dengan jaminan. Sehingga menjadikan orang yang kaya semakin kaya dan orang miskin semakin miskin. Karena adanya penggantian biaya yang harus dibayarkan pemilik barang kepada si pembeli, selain dari pembayaran biaya yang semula didapatkan oleh pemilik barang dari menjual barangnya kepada pembeli. Sehingga dapatlah dikatakan bahwa jual beli dengan hak membeli kembali sama saja seperti hutang piutang dengan agunan, yakni pemberian pinjaman dengan jaminan dan pembayarannya melebihi dari biaya pembayaran semula.

\section{Konsep Bai’ al-Wafâ Menurut Fikih Syafi'i}

Perdagangan atau jual beli secara bahasa berarti al-mubâdalah (saling menukar). ${ }^{15}$ Adapun pengertian jual beli secara istilah, sebagaimana yang akan dijelaskan dalam definisidefinisi berikut ini: Dalam melakukan transaksi jual beli, hal yang penting diperhatikan ialah mencari barang yang halal dan dengan jalan yang halal pula. Artinya, carilah barang yang halal untuk diperjualbelikan kepada orang lain atau diperdagangkan dengan cara yang sejujur-

\footnotetext{
${ }^{15}$ Sayyid Sabiq, Fikih as-Sunnah, trans. Mohammad Tholib, vol. 3 (Semarang: Thoha Putra, 2009), 126.
} 
jujurnya, bersih dari segala sifat yang dapat merusak jual beli seperti halnya penipuan, pencurian, perampasan, riba, dan lain-lain. ${ }^{16}$ Secara etimologis, wafâ (menepati) berlawanan makna dengan alghadr (khianat, tidak menepati janji). Wafâ bi 'ahd artinya dia menepati janji. Wafâ' adalah perangai yang mulia. Aufa al-rajul haqqah artinya dia memberikan hak laki-laki itu secara sempurna. Dinamakan jual beli wafâ karena pembeli wajib menepati dengan syarat. Adapun bai' al-wafâ secara terminologis adalah jual beli dengan syarat, yaitu jika penjual mengembalikan uang hasil penjualan, pembeli mengembalikan barang kepada penjual. ${ }^{17}$ Menurut Sayyid Sabiq dalam fikih sunahnya menyatakan bahwa bai al-wafâ adalah orang yang butuh, menjual suatu barang dengan janji. Janji tersebut menyatakan bila pembayaran telah dipenuhi (dibayar kembali), barang dikembalikan lagi. ${ }^{18}$

Sedang menurut Muhammad Hasbi al-Shiddieqy dalam pengantar fikih Muamalahnya menyatakan bahwa bai al-wafấ adalah akad jual beli dimana salah satu pihak atau penjual mempunyai hak menarik atau membeli kembali pada barang yang telah dijualnya kepada pembeli. Dari pengertian diatas dapat diketahui bahwa bai al-wafâ ini mempunyai batas tenggang waktu yang terbatas misalnya satu tahun, dua tahun dan sebagainya tergantung kesepakatan. Apabila tenggang waktu tersebut telah habis, maka penjual membeli barang itu kembali dari pembelinya. Biasanya barang yang diperjualbelikan dalam bai al-wafâ adalah barang tidak bergerak, seperti lahan perkebunan, rumah, tanah perumahan dan sawah. Sejarah munculnya bai' al-wafâ adalah dalam rangka menghindari terjadinya riba dalam pinjammeminjam, masyarakat Bukhara dan Balkh ketika itu merekayasa sebuah bentuk jual beli yang dikenal kemudian dengan bai al-wafâ, banyak di antara orang kaya ketika itu tidak mau meminjamkan uangnya tanpa ada imbalan yang mereka terima. Sementara itu, banyak pula para peminjam uang tidak mampu melunasi utangnya akibat imbalan yang harus mereka bayarkan. Sementara menurut ulama fikih, imbalan yang diberikan atas dasar pinjammeminjam uang termasuk riba. Barang yang telah dibeli pembeli boleh digunakan oleh si pembeli, hanya saja pembeli tidak boleh menjual barang itu kepada orang lain selain kepada penjual semula, karena barang jaminan yang berada di tangan pemberi utang merupakan jaminan utang selama tenggang waktu yang disepakati tersebut. ${ }^{19}$ Apabila pihak yang berutang telah mempunyai uang untuk melunasi utangnya sebesar harga jual semula pada saat tenggang waktu jatuh tempo, barang tersebut harus diserahkan kembali kepada penjual.

Dari gambaran bai' al-wafâ dapat penulis amati bahwa akadnya terdiri atas tiga bentuk, yaitu: 1) Ketika dilakukan transaksi, akad ini merupakan jual beli karena di dalam akad dijelaskan bahwa transaksi itu adalah jual beli. Misalnya, melalui ucapan penjual "Saya menjual sawah saya kepada engkau seharga lima juta rupiah selama dua tahun"; 2) Setelah transaksi dilaksanakan dan harta beralih ke tangan pembeli, transaksi ini berbentuk ijârah (pinjam-meminjam/sewa-menyewa), karena barang yang dibeli tersebut harus dikembalikan kepada penjual sekalipun pemegang harta itu berhak memanfaatkan dan menikmati hasil barang itu selama waktu yang disepakati; 3) Di akhir akad, ketika tenggang waktu yang disepakati sudah jatuh tempo, bai al-wafâ seperti rahn, karena dengan jatuhnya tempo yang disepakati kedua belah pihak, penjual harus mengembalikan uang kepada pembeli sejumlah harga yang diserahkan pada awal akad, dan pembeli harus mengembalikan barang yang dibeli kepada penjual secara utuh. Yang benar, bahwa jual beli semacam itu tidak dibenarkan, karena tujuan yang sebenarnya adalah riba, yakni dengan cara memberikan uang untuk dibayar secara tertunda, sementara fasilitas penggunaan barang yang digunakan dalam

\footnotetext{
${ }^{16}$ Ibnu Mas'ud and Zainal Abidin, Fikih Madzhab Syafi'i (Bandung: Pustaka Setia, 2000), 24.

${ }^{17}$ Jalâl al-dîn Muhammad bin Ahmad al-Mahallî, Kanz Al-Râghibîn Fi Syarh Minhaj Al-Thâlibîn (Beirut: Dar

Al-Kutub Al-Ilmiyah, 2001), 232.

18 Sabiq, Fikih as-Sunnah, 3:166.

19 al-Mahallî, Kanz Al-Râghibîn, 229-230.
} 
perjanjian dan sejenisnya adalah keuntungannya. Namun sebutan sebagai jual beli pelunasan atau jual beli amanah tidak lepas dari jual beli sepeti itu karena yang dilihat adalah hakikat dan tujuan sesungguhnya dari jual beli tersebut, bukan bentuk aplikatif dan tampilan lahiriahnya saja. ${ }^{20}$ Ibnu Taimiyah menyatakan, "Sejenis jual beli yang mereka perlihatkan yang disebut jual beli amanah yang dalam jual beli itu mereka bersepakat bahwa apabila telah dikembalikan pembayaran si penjual, barang juga dikembalikan, adalah jual beli batil menurut kesepakatan para imam, baik dengan persyaratan yang disebutkan dalam waktu akad atau melalui kesepakatan sebelum akad. Itu pendapat yang tepat dari pada ulama”.

“Amer bin Syu'aib dari ayahnya dari kakeknya mengatakan Rasulullah SAW. bersabda: tidak dihalalkan Salaf (utang) dan membeli dan tidak dihalalkan dua syarat didalam penjualan dan tidak dibolehkan mengambil keuntungan apa yang tidak bisa dijamin dan tidak boleh dijual apa yang ada padamu. HR.Ahmad Abu Daud, Tirmidzi, Nasa'I, dan Ibn Mjjah disyahkan Oleh Tirmidzi, Ibn Khazimah, dan al-Hakim dan diriwayatkan oleh Abu Hanifah dengan kalimat"rasulullah melarang jual beli dengan syarat".

Ulama Syafi'iyyah berpendapat bahwa bai' al-wafâ fasid karena syarat penjual bahwa ia akan mengambil barang dagangannya lagi dari pembeli jika ia mengembalikan uang pembeli yang telah dibayarkan bertentangan dengan tujuan jual beli, yaitu hak milik pembeli terhadap barang dagangan yang dibelinya yang bersifat permanen. ${ }^{21} \mathrm{Hal}$ ini sejalan pula dengan sebuah hadis Rasulullah SAW,"Setiap utang yang dibarengi dengan pemanfaatan (untuk pemberi utang) adalah riba." Karena akad bai al-wafâ sejak semula telah ditegaskan sebagai jual beli, maka pembeli dengan bebas memanfaatkan barang tersebut tanpa batasan waktu. Ulama fikih Syafi'i tidak melegalisasi jual beli ini, alasan mereka diantaranya: (a) Dalam suatu akad jual beli tidak dibenarkan adanya tenggang waktu, karena jual beli adalah akad yang mengakibatkan perpindahan hak milik secara sempurna dari penjual kepada pembeli; (b) Dalam jual beli tidak boleh ada syarat bahwa barang yang dijual itu harus dikembalikan oleh pembeli kepada penjual semula, apabila ia telah siap mengembalikan uang seharga penjualan semula. (c) Bentuk jual beli ini tidak pernah ada di zaman Rasulullah SAW maupun di zaman sahabat. ${ }^{22}$

Adapun dasar atau dalil oleh ulama Syafi'i mengenai ketidakbolehan bai' al-wafâ ada 2 (dua): (1) Berpegang pada kaedah fikih "Yang jadi pegangan dalam akad (kontrak) adalah tujuan dan maknanya, bukan lafadz dan susunan redaksinya”. Maksud dari kaidah ini bahwa tujuan atau makna adalah hakikat dan tiang utama dalam sebuah akad. Sedangkan lafadz dan redaksi kalimat adalah sebuah pengantar atau kulit luar yang akan membawa kepada inti yang dimaksud. Akan tetapi, ini bukan berarti mengabaikan lafadz-lafadz secara keseluruhan, karena lafadz-lafadz itu merupakan acuan makna dan sarana untuk mengungkapkannya. Karena itu yang diperhatikan pertama kali adalah makna-makna zahir dari lafadz-lafadz itu. Apabila sulit untuk disatukan antara lafadz dengan makna yang dimaksud oleh kedua orang yang melakukan akad, maka dikembalikan kepada makna atau tujuan yang dimaksud dan dikesampingkan aspek lafadznya sesuai dengan dalalah atau qarînah, ${ }^{23}$ (2) Berpegang pada dalil Sadd al-Zari'ah, yaitu untuk mencegah terjadinya riba. Dari uraian diatas dapat diketahui bahwa dalil dari ulama syafi'i tidak membolehkan bai' al-wafâ karena jika menurut lafadz atau susunan redaksi bai' al-wafâ merupakan bentuk jual beli akan tetapi jika kita memperhatikan dari tujuan dan pelaksanaan bai' al-wafâ merupakan perpaduan antara jual beli, ijârah dan rahn. Jika dalam pelaksanaannya bai' al-wafâ merupakan jual beli yang

\footnotetext{
20 al-Mahallî, Kanz Al-Râghibîn, 230.

${ }^{21}$ al-Mahallî, Kanz Al-Râghibîn, 229.

22 al-Mahallî, Kanz Al-Râghibîn, 229-230.

${ }^{23}$ Arfan, Kaidah-Kaidah Fikih, 60.
} 
bersyarat yang mengharuskan pembeli mengembalikan barang yang dibelinya setelah ditebus atau dilunasi pembayarannya oleh si pemilik barang, jadi pelaksanaan bai' al-wafâ ini juga merupakan jual beli yang bersyarat yang telah dilarang oleh Rasulullah. Dengan demikian dari pemaparan yang telah dipaparkan peneliti maka dapat peneliti koreksi bahwa bai' alwafâ merupakan bentuk jual beli yang telah dimodifikasi yang tujuan pertamanya untuk menghindari riba akan tetapi dari pelaksanaan yang peneliti amati bahwa jual beli ini masih mengandung riba dan juga merupakan jual beli yang fasid.

\section{Perbandingan Antara Jual Beli Dengan Hak Membeli Kembali Menurut KUPerdata Dan Bai' al-Wafâ Dalam Fikih Syafi'i}

Jual beli dengan hak membeli kembali merupakan suatu tindakan bermuamalah yang mempunyai arti dan peristiwa yang sekilas tampaknya seperti jual beli, meskipun begitu apabila pelaksanaannya tidak dilakukan dengan cara-cara yang benar maka tidak akan sah atau bisa dikatakan batal. Jual beli dengan hak membeli kembali di dalam KUHPerdata dibahas cukup panjang dan sedikit sulit di pahami bahasanya karena merupakan hukum warisan Belanda jadi dari segi kebahasaannya sedikit susah dipahami. Sedangkan jual beli dengan hak membeli kembali atau yang dikenal dalam kajian fikih Syafi'i yakni bai' al-wafâ yang dibahas dalam berbagai kitab fikih Syafi'i klasik yaitu salah satunya ialah kitab Kanz alRâghibîn yang penulis gunakan untuk membandingkan dengan jual beli dengan hak membeli kembali dalam KUHPerdata. Secara umum jual beli dengan hak membeli kembali dalam KUHPerdata dan bai' al-wafâ tinjauan fikih Syafi'i merupakan bentuk yang sama hanya saja pengaturan antara jual beli dengan hak membeli kembali dan bai' al-wafâ berbeda dalam menanggapi bentuk jual beli dengan hak membeli kembali ini. Adapun skripsi ini meneliti tentang perbandingan jual beli dengan hak membeli kembali menurut KUHPerdata dan bai al-wafâ tinjuan fikih Syafi'i dimaksudkan untuk memberikan gambaran tentang peraturan ataupun ketentuan-ketentuan yang terdapat di dalam KUHPerdata dan fikih Syafi'i. Jual beli dengan hak membeli kembali Seperti yang telah dijelaskan menurut pasal 1519 KUHPerdata, kekuasaan untuk membeli kembali barang yang telah dijual diterbitkan dari suatu janji, dimana si penjual diberikan hak untuk mengambil kembali barang yang dijualnya, dengan mengembalikan harga pembelian asal yang disertai penggantian yang disebutkan dalam Pasal 1532 KUHPerdata.

Penggantian di dalam Pasal 1532 adalah penggantian biaya menyelengarakan pembelian dan penyerahan serta perbaikan terhadap barang tersebut adalah hal yang wajar. Sedangkan menurut fikih Syafi'i dalam kitab Kanz al-Râghibîn yakni jual beli yang dilangsungkan dua pihak yang dibarengi dengan syarat bahwa barang yang dijual itu dapat dibeli kembali oleh penjual, apabila tenggang waktu yang ditentukan telah tiba. Apabila pihak yang berutang telah mempunyai uang untuk melunasi utangnya sebesar harga jual semula pada saat tenggang waktu jatuh tempo, barang tersebut harus diserahkan kembali kepada penjual. ${ }^{24}$ Dari pemaparan diatas dapat diketahui bahwa jual beli dengan hak membeli kembali menurut KUHPerdata dan bai' al-wafâ menurut fikih Syafi'i ialah sama akan tetapi terdapat perbedaan yaitu penggantian biaya yang terdapat dalam KUHPerdata yang tidak ada dalam fikih Syafi'i. Dalam kitab Kanz al-Râghibîn tidak ada disebutkan bahwa setelah pemilik barang menebus barangnya dia juga harus membayar lebih dari harga penjualan asal atau biaya penggantian perawatan yang telah disebutkan dalam KUHPerdata. Sedangkan mengenai batasan yang telah dijelaskan sebelumnya bahwa dalam Kitab Undang-Undang Hukum Perdata jual beli dengan hak membeli kembali dibatasi waktu hanya sampai lima tahun, jika lebih dari waktu tersebut maka haruslah diperpendek menjadi lima tahun. Adapun batasan waktu bai' al-wafâ tidak mengatur hal itu.

\footnotetext{
${ }^{24}$ al-Mahallî, Kanz Al-Râghibîn, 229.
} 
Maka dapatlah diketahui sekarang bahwa jual beli dengan hak membeli kembali yang telah diatur dalam Kitab Undang-Undang Hukum Perdata sama saja halnya dengan praktek gadai, yakni hutang dengan jaminan. Akan tetapi dilihat dari praktek yang terjadi di masyarakat bahwa jual beli dengan hak membeli kembali sangatlah merugikan kalangan yang terpaksa karena kebutuhan mendesak yang memerlukan uang hingga berani melakukan transaksi jual beli dengan hak membeli kembali yang akibatnya nanti jika barang yang digadaikan tidak bisa ditebus maka hilanglah hak kepemilikannya. Sedangkan bai' al-wafâ dalam fikih Syafi'i tidak membolehkan transaksi jual beli ini, karena meskipun akadnya adalah jual beli akan tetapi yang terjadi adalah hubungan hutang piutang dengan jaminan, dan transaksi tersebut sama saja seperti rahn, dan juga merupakan jual beli bersyarat yang menggunakan tempo waktu dalam penebusan barang, ini menyalahi dari hakikat jual beli yaitu hak milik sepenuhnya atas barang. Maka ulama Syafi'i mengatakan bahwa jual beli ini hukumnya fasid.

Tabel 1: Perbedaan Jual Beli Dengan Hak Membeli Kembali Menurut KUHPerdata dan Bai' al-wafâ Menurut Fikih Syafi'i

\begin{tabular}{|c|c|c|c|}
\hline No & Persoalan & KUHPerdata & $\begin{array}{c}\text { Fikih Syafi'i (Kitab } \\
\text { Kanz al-Râghibîn) }\end{array}$ \\
\hline 1 & Penggantian Biaya & $\begin{array}{l}\text { Mengatur tentang } \\
\text { penggantian biaya yang } \\
\text { diatur dalam pasal } 1532 \\
\text { bahwa penjual yang } \\
\text { menggunakan perjanjian } \\
\text { membeli tidak saja wajib } \\
\text { mengembalikan seluruh } \\
\text { uang harga pembelian } \\
\text { semula melainkan juga } \\
\text { mengganti semua biaya } \\
\text { menurut hukum. }\end{array}$ & $\begin{array}{l}\text { Tidak mengatur } \\
\text { tentang penggantian } \\
\text { biaya, dalam kitab } \\
\text { kanz al-Râghibîn } \\
\text { hanya menyebutkan } \\
\text { bahwa penjual yang } \\
\text { menggunakan } \\
\text { perjanjian membeli } \\
\text { kembali hanya } \\
\text { mengembalikan } \\
\text { seluruh uang, harga } \\
\text { pembelian semula. }\end{array}$ \\
\hline 2 & Batas Maksimal Perjanjian & $\begin{array}{l}\text { Mengatur tentang } \\
\text { penggantian biaya yang } \\
\text { diatur dalam pasal } 1532 \\
\text { bahwa penjual yang } \\
\text { menggunakan perjanjian } \\
\text { membeli tidak saja wajib } \\
\text { mengembalikan seluruh } \\
\text { uang harga pembelian } \\
\text { semula melainkan juga } \\
\text { mengganti semua biaya } \\
\text { menurut hukum }\end{array}$ & $\begin{array}{c}\text { Menurut kesepakatan } \\
\text { kedua belah pihak } \\
\text { yang membuat } \\
\text { perjanjian. }\end{array}$ \\
\hline 3 & $\begin{array}{l}\text { Hukum dari jual beli dengan } \\
\text { hak membeli kembali dan bai' } \\
\text { al-wafâ }\end{array}$ & $\begin{array}{l}\text { Menurut KUHPerdata jual } \\
\text { beli dengan hak membeli } \\
\text { kembali dibolehkan dan } \\
\text { dalam KUHPerdata }\end{array}$ & $\begin{array}{l}\text { Menurut fikih Syafi'i } \\
\text { dalam kitab kanz al- } \\
\text { Râghibîn ulama } \\
\text { Syafi'i menganggap }\end{array}$ \\
\hline
\end{tabular}




\begin{tabular}{|l|l|l|}
\hline & $\begin{array}{l}\text { ketentuan tentang jual beli } \\
\text { dengan hak membeli } \\
\text { kembali diatur dalam pasal } \\
1519-1532\end{array}$ & $\begin{array}{l}\text { jual beli ini adalah } \\
\text { fasid karena } \\
\text { merupakan jual beli } \\
\text { bersyarat yang } \\
\text { bertentangan dengan } \\
\text { dengan tujuan jual } \\
\text { beli, yaitu hak milik } \\
\text { pembeli terhadap } \\
\text { barang dagangan } \\
\text { yang dibelinya yang } \\
\text { bersifat permanen. }\end{array}$ \\
\hline
\end{tabular}

Sementara titik temu (Persamaan) antara Jual beli dengan hak membeli kembali tinjauan KUHPerdata dan bai' al-wafâ tinjauan fikih Syafi'i adalah Jual beli dengan hak membeli kembali menurut KUHPerdata dan bai' al-wafâ menurut fikih Syafi'i adalah sama-sama bertujuan untuk tolong menolong kepada orang yang membutuhkan uang cash dengan cara menjaminkan barangnya yang kemudian akan dibeli kembali. Jual beli dengan hak membeli kembali menurut KUHPerdata dan bai' al-wafâ menurut fikih Syafi'i adalah sama-sama tidak membolehkan kepada pembeli untuk menjual barang kepada pihak ketiga atau pihak lain, dan wajib mengembalikan barang apabila barang telah ditebus oleh pemilik barang.

Tabel 2: Persamaan Jual Beli dengan Hak Membeli Kembali dengan Bai' al-Wafa'

\begin{tabular}{|c|l|}
\hline No. & \multicolumn{1}{|c|}{ Persamaan } \\
\hline 1. & $\begin{array}{l}\text { Jual Beli Dengan Hak Membeli Kembali menurut KUHPerdata dan Bai al- } \\
\text { Wafâ menurut Fikih Syafi'i bertujuan untuk saling tolong menolong } \\
\text { terhadap orang yang membutuhkan uang. }\end{array}$ \\
\hline 2. & $\begin{array}{l}\text { Jual Beli Dengan Hak Membeli Kembali menurut KUHPerdata dan Bai al- } \\
\text { Wafâ menurut Fikih Syafi'i sama-sama tidak membolehkan pembeli untuk } \\
\text { menjual asset/properti kepada pihak ketiga atau pihak lain, dan mewajibkan } \\
\text { pembeli untuk mengembalikan barang apabila barang telah ditebus oleh } \\
\text { pemilik barang. }\end{array}$ \\
\hline
\end{tabular}

\section{Kesimpulan}

Berdasarkan dari paparan yang telah penulis uraikan sebelumnya maka dapat disimpulkan bahwa konsep jual beli dengan hak membeli kembali tinjauan Kitab Undang-Undang Hukum Perdata adalah menurut Pasal 1519 KUHPerdata menjelaskan: ' kekuasaan untuk membeli kembali barang yang telah dijual diterbitkan dari suatu janji, dimana si penjual diberikan hak untuk mengambil kembali barang yang dijualnya, dengan mengembalikan harga pembelian asal yang disertai penggantian yang disebutkan dalam Pasal 1532 KUHPerdata”. Dalam jual beli ini ada suatu jangka waktu tertentu yang diperjanjikan untuk menebus kembali barang yang telah dijual dan jangka waktu jual beli ini tidak boleh lebih dari lima tahun. Sedangkan bai' al-wafâ menurut fikih Syafi'i yaitu jual beli yang dilangsungkan dua pihak yang dibarengi dengan syarat bahwa yang dijual itu dapat dibeli kembali oleh penjual, apabila tenggang waktu yang telah ditentukan tiba, sedangkan barang yang dijual tersebut bebas dipergunakan oleh pembeli

Perbandingan jual beli dengan hak membeli kembali tinjauan Kitab Undang-Undang Hukum Perdata dan bai' al-wafâ tinjauan fiqh syafi'i adalah jika dalam jual beli dengan hak membeli kembali terdapat batasan waktu maksimal lima tahun sedangkan dalam bai' al-wafâ tidak ada ketentuan khusus yang mengatur mengenai batasan waktu. Dalam jual beli dengan hak membeli kembali juga mengatur tentang penggantian biaya perawatan barang dan lain sebagainya, sedangkan bai' al-wafâ tidak ada menyinggung tentang penggantian biaya perawatan, yang dibayarkan hanya 
harga awal pembelian, terakhir mengenai hukum dari jual beli dengan hak membeli kembali dalam KUHPerdata banyak dipertentangkan dalam putusan Mahkamah Agung diantaranya Putusan MA. No. $1729 \mathrm{~K} / \mathrm{Pdt} / 2004$ yang menyatakan bahwa jual beli dengan hak membeli kembali tidak diperbolehkan, sedangkan bai' al-wafâ hukumnya dalam fikih Syafi'i kitab Kanz al-Râghibin Fi Syarh Minhaj al-Thâlibin merupakan jual beli yang fasid.

\section{Daftar Pustaka}

Arfan, Abbas. Kaidah-Kaidah Fikih Muamalah Dan Aplikasinya Dalam Ekonomi Islam \& Perbankan Syariah. Malang: UIN-Malang Press, 2012.

Ibrahim, Johnny. Teori Dan Metode Penelitian Hukum Normatif. Malang: Bayu Media Publishing, 2006.

Mahallî, Jalâl al-dîn Muhammad bin Ahmad al-. Kanz Al-Râghibîn Fi Syarh Minhaj Al-Thâlibîn. Beirut: Dar Al-Kutub Al-Ilmiyah, 2001.

Marzuki, Peter Mahmud. Penelitian Hukum. Jakarta: Kencana, 2010.

Mas'ud, Ibnu, and Zainal Abidin. Fikih Madzhab Syafi'i. Bandung: Pustaka Setia, 2000.

Muhammad, Abdulkadir. Hukum Dan Penelitian Hukum. Bandung: Citra Aditya Bakti, 2004.

Nasution, Bahder Johan. Metode Penelitian Ilmu Hukum. Bandung: Mandar Maju, 2008.

Sabiq, Sayyid. Fikih as-Sunnah. Translated by Mohammad Tholib. Vol. 3. Semarang: Thoha Putra, 2009.

Soekanto, Soerjono, and Sri Mamudji. Penelitian Hukum Normatif: Suatu Tinjauan Singkat. Jakarta: RajaGrafindo Persada, 2006.

Subekti, and R. Tjitrosudibio. Kitab Undang-Undang Hukum Perdata. Jakarta: Pradnya Paramita, 2007.

Suharnoko. Hukum Perjanjian : Teori Dan Analisa Kasus. Jakarta: Kencana Prenada Media Group, 2004.

Widjaja, Gunawan, and Kartini Muljadi. Jual Beli. Jakarta: RajaGrafindo Persada, 2003.

Widjaya, I.G. Rai. Merancang Suatu Kontrak (Contract Drafting), Teori Dan Praktek. Jakarta: Megapoin, 2003.

Undang-Undang Nomor 5 Tahun 1960 tentang Pokok-Pokok Agraria 